\title{
Filosofi Hidup Komunitas Masyarakat Adat Sunda Kampung Naga Ditinjau dari Pranata Keagamaan
}

\author{
Oleh \\ Tenny Sudjatnika, M.Ag \\ Dosen Studi Islam Fakultas Adab dan Humaniora \\ UIN Sunan Gunung Djati Bandung
}

\begin{abstract}
Abstrak
Komunitas adat di Indonesia merupakan kelompok masyarakat yang menempati wilayah tertentu yang dicirikan oleh ketaatan dalam menjalankan adat istiadat warisan leluhur. Di Indonesai bagian Jawa barat terdapat 14 komunitas adat yang mempertahankan nilai-nilai adat dan tradisinya di tengah-tengah lingkungan modern saat ini. Penelitian menggunakan jenis kualitatif melalui analisis deskriptif melalui dokumen dan survei. Hasil penelitian menunjukkan bahwa Komunitas Adat di Jawa Barat, agama tidak dijadikan suatu sistem yang mengatur tata keimanan dan peribadatan, tetapi difungsikan sebagai edukasi, penyelamatan, pengawasan sosial, pembentuk persaudaraan dan transformatif dengan konsep mengikat diri dengan Tuhannya. Pranata keagamaan terselenggara berdasarkan filosofi kehidupan "Berusaha mencari kesempurnaan" dengan maksud untuk mengetahui asal mula dan akhir. Orientasinya adalah kembali kepada Tuhan Yang Maha Esa dengan harapan memperoleh suatu ketentraman. Sumber ajaran difusikan dari ajaran agama terdahulu dengan ajaran Islam yang diinternalisasi pada nilai-nilai tradisi budaya leluhur. Nilai Instrumennya berpangkal dari nilai achieving seseorang yang diinginkan warga pada masa hidupnya. Sistem nilai dibangun berdasarkan hirarki nilai individu ke dalam term kesadaran yang mengkolektif. Sistem sosial dibangun atas situasi keseimbangan antara sosial dan agama yang datang dikonstruk pada situasi normal melalui reorganisasi. Rekomendasinya, perlu pelestarian prinsip budaya kesundaan yang diadaptasi pada situasi modern agar tidak tergerus jaman dengan cara dukungan moril, ilmu pengetahuan, toleransi.

Kata Kunci: fungsi sistem keyakinan, orientasi keyakinan, sumber ajaran, sistem nilai, sistem sosial.
\end{abstract}

\section{Pendahuluan}

Di Indonesia ada banyak yang bisa ditemukan kelompok masyarakat yang masih menjunjung tinggi kehidupan dengan nilai-nilai adat. Komunitas adat ini merupakan kelompok masyarakat yang menempati wilayah tertentu, dapat menjalin interaksi serta dapat dicirikan oleh ketaatan dalam menjalankan adat istiadat warisan leluhur. Hasil kajian para peneliti BPSNT Bandung mengungkapkan bahwa warga komunitas adat merupakan contoh komunitas yang berusaha menyesuaikan diri dengan lingkungan alam dan berupaya mempertahankan kondisi lingkungan alamnya dengan tetap mentaati aturan adat warisan para leluhur sehingga setiap komunitas adat tersebut memiliki ciri khas yang membedakan dengan masyarakat lain. 


\section{Jurnal al-Tsaqafa Volume 15, No. 01, Juli 2018}

(BPSNT Wilayah Kerja Propinsi Jawa Barat, tanpa tahun ).

Di Tasikmalaya terdapat sekelompok warga kampung dengan sebutan Kampung Naga. Kampung Naga merupakan sebuah kampung adat yang masih lestari, dimana masyarakatnya masih memegang adat tradisi nenek moyang mereka. Mereka menolak intervensi dari luar karena hal itu dirasakan mencampuri dan merusak kelestariannya. Mereka nampak sangat menghargai, menjaga serta merealisasikan apa yang mereka yakini. Cara mereka mempercayai dan menjaganya tidak mereka rasakan sebagai sebuah beban, tetapi hanya dengan kata "pamali" masyarakat kampung Naga segan dan takut untuk melanggarnya. Pantangan atau pamali adalah sebuah hukum yang tidak tertulis, namun bagi mereka merupakan aturan adat yang harus kukuh dipatuhi.

Aturan-aturan adat yang mereka yakini mempunyai makna atau fungsi tersendiri bagi mereka. Aturan tersebut berfungsi sebagai mekanisme kontrol dalam kebudayaan yang menahan ekploitasi alam secara semena-mena. Selain itu mereka melakukannya agar memiliki filosofi hidup yang sederhana dan prinsip hidup tidak berlebihan tetapi tetap berpegang teguh pada prinsip kebersamaan, sehingga mereka dapat mempertahankan dan merasakan keseimbangan lingkungan baik secara fisik maupun sosial. Adapun mekanisme dalam menjalankan aturan tersebut, mereka lakukan melalui sanksi moral sebagai pelanggaran nilai-nilai etika yang disinyalir akan terjadinya malapetaka.

Dalam perspektif sosiologi, sistem kepercayaan diatas dapat diwujudkan dalam perilaku sosial. Wujud prilaku tersebut dapat dipandang sebagai sebuah agama. Perilaku-perilaku sosial yang diperankan berkaitan dengan sistem keyakinan dari ajaran agama yang dianutnya dan digerakkan oleh kekuatan yang didasarkan dari nilai-nilai ajaran agama yang diinternalisasi dari sebelumnya. Hal ini berkaitan dengan pengalaman manusia baik sebagai individu maupun kelompok. (Kahmad, 2006).

Ada dua pendekatan yang dapat mengungkap gejala sosial di atas, diantaranya bisa dengan menggunakan pendekatan teologis atau melalui pendekatan keilmuan. Dalam menggunakan pendekatan keilmuan ada dua bidang kajian penelitian antara lain bidang ilmu budaya dan bidang ilmu sosial. Bidang ilmu budaya, sebuah masalah dapat diteliti melalui cara-cara yang diatur oleh aturanaturan kebudayaan. Sementara bidang ilmu sosial, penelitian dapat digunakan melalui keteraturan-keteraturan yang terdapat dalam masyarakat pemeluk agama sebagai akibat dari terjadinya proses interksi diantara 
anggota masyarakat, antar kelompok, antar suatu masyarakat beragama dengan masyarakat beragama yang lain (Kahmad, Sosiologi Agama, 2006).

Penelitian ini, meneliti tentang eksistensi komunitas adat yang dikhususkan pada warga Kampung Naga dalam hal pranata keberagamaan mereka berdasarkan filosofi hidupnya. Studi previus yang peneliti temukan dari penelitian tentang Kampung Naga adalah hal keterkaitan nilainilai kearifan lokal kampung Naga. Maka untuk membedakan penelitian ini dengan penelitian lain, peneliti meninjau dari aspek sosiologi agama kampung naga berdasarkan filosofi hidupnya yang ditinjau dari pranata keagamaan. Dengan demikian judul dari peneliti ini adalah Filosofi Hidup Kampung Naga Ditinjau dari Pranata Keagamaan.

Komunitas Kampung Adat di Jawa Barat telah banyak diteliti oleh ahli budaya, sementara dalam kajian sosiologi agama belum banyak terdapat penelitian. Maka untuk mendapatkan hasil penelitian yang terfokus dan mendalam penelitian ini dibatasi pada aspek pranata keagamaan. Dengan batasan tersebut peneliti berusaha mencari jawaban atas permasalahanpermasalahan (1) Filososfi hidup Warga Kampung Naga, (2) Latar belakang ritus keagamaan warga Kampung Naga terhadap filosofi hidup, (3) Impelentasi pranata sosial warga kampung Naga terhadap pranata keberagamaan.

\section{Pembahasan}

\section{Landasan Teori}

Dalam kajian ekologi manusia yaitu suatu ilmu yang mempelajari suatu jenis organisasi atau satu jenis makhluk hidup, di dalamnya mempelajari bagaimana manusia berinteraksi dengan komponen alam secara timbal balik maupun searah, (Mufisofyan, 2010). merupakan suatu ilmu dasar dalam memahami dan mengkaji bagaimana ekosistem kehidupan suatu makhluk hidup bekerja dalam sistem kehidupannya, kelangsungan hidupnya, cara mencukupi kehidupannya, bentuk-bentuk intraksi dengan komponen atau species lainnya, adaptasi dan toleransinya terhadap perubahan, terhadap pertumbuhan dan perkembangbiakannya.

Dalam upaya memahami bagaimana dan mengapa individu berprilaku, berfikir dan memiliki perasaan dalam konteks situasi sosial yaitu kehadiran orang lain secara nyata maupun secara imajinasi merupakan fokus utama pembahasan psikologi sosial. (Byrne, 2003). Didalamnya mencoba memahami faktorfaktor yang menyebabkan kondisi yang membentuk prilaku sosial dan pemikiran sosial berupa perilaku, perasaan, ingatan dan penyimpulan mereka tentang sesuatu 
dalam berbagai situasi sosial. Robert membagi ke dalam lima sub utama penyebab prilaku sosial dan pemikiran sosial pada diri individu antara lain: prilaku dan karakter orang lain, proses-proses kognitif, variable-variabel lingkungan yakni pengaruh dari lingkungan fisik, konteks budaya, dan faktor biologis. (Byrne, Psikologi Agama, 2003).

Ditinjau dari fakta sosial, prilaku dan pemikirian sosial tersebut terjadi ketika individu mulai berhubungan dengan individu lain yang berada dalam suatu lingkungan sosial dengan seperangkat aturan, hukum, norma dan nilai yang mengikat kebebasan individu dengan berbagai kewajiban moral terhadap individu lainnya, sehingga ia harus mengikuti adat istiadat, norma, tata cara bertoleransi yang lazim dilakukan di dalam anggota masyarakat.

Berbagai tindakan dalam melakukan hubungan yang terpola tersebut disebut dengan fakta sosial yaitu suatu konsep dasar dari sosiologi yang berhubungan dengan keberadaan individu di masyarakat. Fakta sosial ini mengantarkan kepada pembahasan tentang hubungan timbal balik antara individu dengan masyarakat terutama dalam hal peranan masyarakat dalam membentuk kepribadian individu. (Kahmad, Sosiologi Agama, 2006).
Dalam perspektif sosiologi, wujud prilaku sosial yang diperankan berkaitan dengan pengalaman manusia baik secara individu maupun kelompok terikat pada suatu sistem keyakinan dari ajaran agama yang dianut. Prilaku-prilaku yang digerakan oleh suatu kekuatan dari dalam didasarkan pada nilai-nilai ajaran agama yang menginternalisasi sebelumnya. Wach beranggapan bahwa keagamaan yang bersifat subjektif dapat diobjektifkan dalam berbagai macam ungkapan dan ungkapan tersebut mempunyai struktur tertentu yang dapat dipahami. Dadang Kahmad mengutip C.Y Glock dan R. Stark bahwa terdapat lima dimensi beragama yang terstruktur antara lain dimensi keyakinan, dimensi praktik agama, dimensi pengalaman, dimensi pengetahuan dan dimensi konsekuensi. (Kahmad, Sosiologi Agama, 2006).

Timbal balik antara pengaruh agama terhadap masyarakat dan pengaruh masyarakat terhadap agama menimbulkan hubungan Interdipendensi antara keduanya. Maka esoterik dari suatu kepercayaan ataupun agama pada dasarnya tidak berdiri sendiri melainkan berkaitan dengan dimensi-dimensi lain seperti struktur sosial dimana suatu subtansi ajaran dimanivestasikan oleh para pemeluknya sehingga dalam konteks tertentu agama dapat beradaptasi. Pada konteks lain, agama 
dapat berfungsi sebagai media legitimasi proses perubahan disekitar kehidupan para pemeluknya. Dengan demikian relasi manusia dan masyarakat dapat merubah struktur sosial, mempengaruhi dan dibentuk oleh institui sosial

Hubungan manusia dengan masyarakat dalam proses dialektika menimbulkan keadaan ekternal dimana manusia mengekspresikan dirinya melalui bangunan dunianya. Dalam keadaan ini masyarakat menjadi realistis objektif. Dengan segala pranata sosialnya, masyarakat mempengaruhi pembentukan prilaku, yang kemudian dibentuk kembali oleh manusia melalui proses internalisasi.

Koentjaraningrat mendefinisikan pranata atau disebut juga institution adalah suatu sistem norma khusus yang menata suatu rangkaian tindakan berpola mantap guna memenuhi suatu keperluan khusus dari manusia dalam kehidupan masyarakat. (Koencaraningrat, 1985). Hal itu berarti pranata dijabarkan dalam berbagai lembaga sosial dalam bentuk organisasi sosial yang dapat memenuhi semua kebutuhan manusia bisa berpedoman pada pola-pola hubungan yang resmi maupun yang tidak resmi. Maka pranata sosial yang berhubungan dengan kehidupan beragama di suatu masyarakat merupakan pemenuhan kebutuhan anggota masyarakat dalam mengabdi kepada
Tuhannya, yang menurut Dadang Kahmad kebutuhan pranata sosial tersebut antara lain ibadah, pendidikan agama dan dakwah, hukum dan pengadilan agama, partai politik berdasarkan agama, ekonomi berdasarkan agama, keluarga, sosial, pertahanan, ilmu pengetahuan, kesusastraan dan kesenian. (Kahmad, Sosiologi Agama, 2006).

\section{Filososfi hidup Warga Kampung Naga}

Masyarakat adat kampung Naga memiliki filososfi hidup bersama alam. Mereka memahami bahwa alam ada bukanlah tersedia untuk di rusak, alam ada karena ingin berbagi kehiduapan dengan manusia. Dengan kata lain manusia ingin hidup dari alam dan alam ingin hidup dari manusia. Manusia dan alam saling ketergantungan (mutualisme). Pepatahnya adalah jika ingin mengelola alam maka harus bersahabat dengan alam dengan cara ngarawat dan ngarumat.

Oleh karena itu, masyarakat Adat Kampung Naga sangat memegang teguh etika yang telah dipertahankan. Sikap saling menghargai dan hukum aturan yang berlaku dibuat dengan ungkapan pamali. Mereka menjungjung hukum pamali sebagai bentuk aturan mengatur prilaku. Kata pamali dianggap sebagai kata yang menerangkan tentang larangan untuk melakukan segala sesuatu yang dianggap tabu yakni suatu hal 


\section{Jurnal al-Tsaqafa Volume 15, No. 01, Juli 2018}

yang dianggap suci. Contohnya larangan mengerjakan sesuatu yang tidak baik dengan menghadap kiblat, buang air, menjulurkan kaki ke arah kiblat. Kiblat yang dimaksud adalah arah untuk beribadah. Segala sesuatu yang dianggap buruk dilarang menghadap kiblat. Oleh karena itu kata pamali diyakini sebagai upaya mentaati etika yang baik yang diajarkan secara turun termurun.

Dilihat dari sejarahya, kampung Naga tidak diketahui asal usulnya "Pareum Obor". Hal ini disebabkan karena terjadi pembakaran kampung Naga yang dilakukan pada masa DI/TII pada tahun 1956. Namun berdasarkan cerita mereka, sejarahnya diawali pada masa kewalian Syek Syarif Hidayatulloh atau disebut juga Sunan Gunung Djati yang menugasi abdinya bernama Singaparna untuk menyebarkan agama Islam ke sebelah Barat hingga sampailah di daerah Neglasari yang berada di Kecamatan Salawu Kabupaten Tasikmalaya.

Ajaran yang diberikan sifatnya riyadlah yakni kesucian dan kebersihan hati agar dapat memperoleh pengalaman realitas hakiki berdasarkan intuisi. Dari pengalamannya, ajaran ini diyakini bahwa jiwa mengalami keterbukaan (mukasyafah) sehingga mampu memancarkan cahaya dari sumber cahaya itu sendiri. Ajaran tersebut diajarkan secara turun temurun melalui metode amanah, wasiat dan akibat. Amanah adalah pesan moral berupa nilainilai luhur yang dapat dijadikan tauladan. Wasiat adalah pesan yang dikatakan atau ditulis oleh orang yang akan meninggal. Akibat adalah hasil dari suatu perbuatan dan keputusan dari amanah dan wasiat. Ketiga metode tersebut dianggap sebagai penghormatan terhadap nenek moyang (karuhun), maka jika bukan berasal dari karuhun dianggap tabu. Dalam masalah tabu ini mereka meyakini adanya waktuwaktu tertentu yang dianggap buruk, seperti pantangan membangun rumah, perkawinan, khitanan atau upacara adat. Oleh karena itu mereka melakukan perhitungan hari baik.

\section{Ritus keagamaan}

Dilihat dari ritus religinya, masyarakat komunitas adat kampung naga memiliki pemahaman dari budaya Islam. Mereka melakukan pengajaran mengaji, tahlilan dengan membaca Al Qur'an satu kali khataman dalam semalam. Tetapi mereka tidak melakukan ibadah haji melainkan cukup dengan menjalankan upacara Hajat Sasih yang bertepatan pada Hari Raya Haji (10 Dzulhijaah) sebagai penggantinya. Dalam 1 tahun mereka melaksanakan ziarah ke makam leluhur 6 kali secara berkala. Namun ada hari-hari yang dilarang untuk melakukkan ritus adat antara lain hari Selasa, Rabu dan Sabtu. 
Dalam kesehariannya, nampak mereka memiliki komunikasi non-verbal seperti tanda-tanda di pagar dengan posisi berdiri seperti biasa menandakan milik pribadi, jika berbentuk silang merupakan tanda keramat. Bentuk tanduk diatap menandakan penduduk asli orang Sunda. Simbol rumah-rumah menggunakan dasar tubuh manusia yakni kepala, tubuh dan kaki yang bisa berdiri tegak. Oleh karenanya, atap diibaratkan kepala, ruangan bagian dalam diibaratkan perut, dan pondasi diibaratkan kaki.

Kepercayaan terhadap makhluk halus masih dipegang kuat, seperti jurig cai (hantu air), ririwa (hantu berbentuk manusia), kunti anak (hantu perempuan hamil), yang diyakini bahwa mereka tinggal di tempat yang sanget (angker). Sistem kepercayaan mereka ditandai dengan pemahaman perbatasan tempat dan daerah seperti batas sungai, batas pekarangan, tempat air masuk (hulu waton), tempat lereng bukit (tempat antara pemukiman dan hutan) yang diyakini sebagai adanya kekuatan-kekuatan tertentu. Oleh karena itu bentuk ritualnya mereka melakukan sesajen.

\section{Implementasi}

Pranata

Keagamaan terhadap Pranata Sosial
Ditinjau dari pranata keagamaan, masyarakat komunitas adat kampung Naga, agama tidak dijadikan suatu sistem yang mengatur tata keimanan dan peribadatan, tetapi keyakinannaya diadopsi dari ajaran Islam yang diasimilasi dengan ajaran leluhur nenek moyang mereka yang difungsikan sebagai edukasi, penyelamatan, pengawasan sosial, pembentuk persaudaraan dan transformatif dengan konsep mengikat diri dengan Tuhannya. Pranata keagamaan terselenggara berdasarkan filosofi kehidupan "Berusaha mencari kesempurnaan" yang diadopsi dari ajaran Islam dengan maksud untuk mengetahui asal mula hidup dan akhir hidup manusia berasal dan kembali pada Tuhan Yang Maha Esa. Orientasinya adalah kembali kepada Tuhan Yang Maha Esa bahwa mereka harus memiliki tujuan hidup dengan harapan memperoleh suatu ketentraman. Sumber ajaran difusikan dari ajaran agama Islam dan budaya ajaran sebelumnya yakni ajaran Hindu dan Budha yang diinternalisasi pada nilai-nilai tradisi budaya leluhur. Nilai Instrumennya berpangkal dari nilai achieving seseorang yang diinginkan warga pada masa hidupnya. Sistem nilai yang dibangun berdasarkan hirarki nilai individu ke dalam term kesadaran yang mengkolektif. Adapun sistem sosial dibangun atas situasi 
Jurnal al-Tsaqafa Volume 15, No. 01, Juli 2018

keseimbangan antara pranata sosial dan pranata keagamaan yang dikonstruk pada situasi normal melalui reorganisasi ajaran.

\section{Penutup}

Ekosistem kehidupan suatu manusia bekerja dalam sistem kehidupannya, kelangsungan hidupnya, cara mencukupi kehidupannya, bentuk-bentuk intraksi, adaptasi dan toleransinya terhadap perubahan, terhadap pertumbuhan dan perkembangbiakannya. Maka cara masyarakat kampung Naga berprilaku, berfikir dan memiliki perasaan dalam konteks situasi sosial dipahami berdasarkan faktor-faktor yang disebabkan dari kondisi masa lalu yang dialami leluhurnya. Prilaku sosial dan pemikiran sosial pada diri individu leluhurnya dipahami sebagai warisan, dan wasiat yang harus ditaati sehingga prilaku dan karakter orang lain, proses-proses kognitif, serta variablevariabel lingkungan sangat mempengaruhi lingkungan fisik, konteks budaya, dan faktor biologis mereka. Oleh karena itu, wujud prilaku sosial yang diperankan berkaitan dengan pengalaman mereka terikat dari sistem keyakinan dari ajaran agama-agama khususnya agama Islam yang diinternalisasi menjadi ajaran leluhur yang dianut. Prilaku-prilaku digerakan oleh suatu kekuatan dari dalam didasarkan pada nilainilai ajaran keyakinan tentang tabu dan pamali yang diinternalisasi dari ajaran agama menjadi sebuah karakter masyarakat adat Kampung Naga..

\section{Daftar Pustaka}

BPSNT Wilayah Kerja Propinsi Jawa Barat, D. J. (tanpa tahun ). Komunitas Adat di Jawa Barat. Bandung: Balai Pelestarian Sejarah dan Nilai Tradisional. Byrne, R. A. (2003). Psikologi Agama. Jakarta: Erlangga.

Byrne, R. A. (2003). Psikologi Sosial. Jakarta: Erlangga.

Kahmad, D. (2006). Sosiologi Agama. Bandung: Remaja Rosda Karya. Koencaraningrat. (1985). Oengantar Ilmu Antropologi. Bandung: Angkasa baru. Mufisofyan, S. (2010). Islam \& Ekologi Manusia. Bandung: Nuansa. 